\title{
MULAI LAWAN BISMILLAH: Religiosity of the Banjar People in the Banjar Songs Composed by Anang Ardiansyah
}

\author{
Nasrullah \\ University of Lambung Mangkurat, Banjarmasin \\ Email: Nasrullah@ulm.ac.id
}

\begin{abstract}
Local folk songs are often only enjoyed by local people and, of course, only a few of these songs can become national songs. However, through the song called Paris Barantai composed by Anang Ardiansyah, the Banjar song can become a nationally recognized regional folk song. In addition, Anang Ardiansyah's other songs have a message or religious content that reflects the Islamic culture of the Banjar community. Therefore, this paper explores religious content of four songs composed by Anang Ardiansyah with the aim that the local folk songs are not only sung but reinforce the distribution of religious values and knowledge in relation to the Banjar culture. The results of this paper describe the religious practice of urang (people of) Banjar related to faith, prayer and shalawat in everyday life and the term haram menyarah (surrender is forbidden) as Banjar people's struggle doctrine depicted from the Banjar song composed by Anang Ardiansyah. Therefore, through these songs it becomes an important part of the efforts to strengthen the Banjar religious identity and religious value distribution will take place continuously.
\end{abstract}

Keywords: Anang Ardiansyah, religiosity, haram manyarah

\section{INTRODUCTION}

"Wayah pang sudah

Hari baganti Musim

Wayah pang sudah

Kotabaru gunungnya bamega

Bamega umpat manampur di sala karang"

(Paris Barantai, composed by Anang Ardiansyah)

In 2017, there were two controversial issues related to the international and national music world. First, there was still sensitivity among the people of the world in giving judgment of a song lyrics like Despacito sung by Justin Beiber, 
because the lyric is considered vulgar that this song was rejected in Malaysia (Alkhalisi 2017). This rejection did not seem to happen in Indonesia because electronic mass media such as radio or television did not air it but only carried the news of the controversial issue. Second, there was an international event where a South Kalimantan song entitled Paris Barantai composed by Anang Ardiansyah, as quoted above, sung by the Padjadjaran University Student Choir won the first prize of folksong category in 54th International Competition of Choral Singing in Spittal an der Drau, Austria, 7-9 July 2017. They also won the second place of the choral works category. But Metro TV one of the Indonesian national private TV stations mentioned in its headline news that the song Paris Barantai had been written Ken Steven and it received a lot of reactions from social media users, especially residents of South Kalimantan. Ken Steven who did not write the song immediately wrote an apology to the Banjar people and the songwriter of Paris Barantai, the late Anang Ardiansyah (Anonymous 2017).

Based on these two events, it can be understood that the lyrics of the song as a work of art is not only seen from the aesthetic factor of the beauty of chanting, but also to the depth of the meaning of the lyrics and the importance of maintaining the authority of the songwriter as the copyright owner. This is why art is a 'space' for the discourse where the 'mind' and 'taste' lie, so that the cultural configuration (Melalatoa 2000,2) is encompassed, in spite of the fact that artwork is basically a mere fantasy, but when it is tangent to the political system then art is a political attitude. The work of art can actually be interpreted in various ways for its audience, especially when it is released from its creators to become public property (Mundayat 2006). This is seen, for example, in Java there was a legendary artist named Gesang famous for the song Bengawan Solo, Anang Ardiansyah from Kalimantan is his equivalent. M. Syaifullah, a Kompas journalist, wrote about the heyday of Anang Ardiansyah. The era of 1980s indeed belonged to Anang Ardiansyah. It was a time when many of his songs were recorded, either in the form of his own album or along with other banjar songs composed by other artists. The songs were arranged in the genres of pop, latin, jazz, and Malay. The song characters and lyrics that are easy to digest and have a moral message made them popular.

The lyrics of Banjar songs that he composed are mostly derived from folk songs in the form of pantun which in the past developed on the banks of rivers, coastal areas, and on lands. There are rantauan songs in the form of folk songs that flourish on the banks of the river with characteristics that resemble river waves. The shrill sounds like lamenting fate. While there are pandahan songs in the form of songs on japin dance that lives on in Banua Anam. These songs 
are sung during mairik banih (removing the grains of rice from the stalks by trampling). Lastly, there are pasisiran songs that developed in Kotabaru area, usually sung to accompany the japin sigam dance (Syaifullah, 2008).

Hundreds of songs have been written Anang Ardiansyah compiled in various albums of songs: Kambang Goyang (1983), Ballads of Faith (1982), Galuh Banjar (1985), Latinia (as the tile suggests, they have Latin rhythm, 1986), Diang Katinting (1987), Curiak ( 1988). The songs of Anang Ardiansyah are timeless, as they are always played from gramophones, cassettes, VCD / DVD players, sung in weddings to official events, into ringing tones or i-ring tones. The songs also often become background music in various local television shows, and in addition, one of the songs Anang Ardiansyah wrote was popularized by the Radja band which was sung in different versions or rearranged. Therefore, this paper seeks to show Banjar urban religiosity through texts on Anang Ardiansyah songs by recounting and discussing the contents of the Banjar songs. To date, the religious content in songs is more identical to the spiritual songs or those sung by Nasyid groups, such as Rayhan, Debu, to singers Haddad Alwi and Sulis or Opick who sang sholawat to Prophet Muhammad SAW. In the dangdut music genre, Rhoma Irama's name is synonymous with singing the teachings of Islam, and he is not only referred to as the king of Dangdut and his religious poems, even his band is called the Voice of Moslem.

A lot of other variants of Islamic music are also found in qasidah, tambourine, and even Arabic things because, since the beginnings of Islam in Indonesia in the sixteenth century, Indonesian Muslims have been learning to recite the Qur'an, and to sing other religious musical genres with the language, melodies, rhythms, timbres, and musical aesthetics of Arab peoples (Rasusmen, 2005). In contrast, there is not much local music or regional songs - except Kiai Kanjeng and Emha Ainun Nadjib - who are shown conveying a religious message. Outside of Islamic music echoed from regional songs, it turns out that music in the past was considered all "musical" art closely related to the cult, especially the parties, where the actual function lies (Huizinga 1990: 221). Similarly, Induan Hiling, a female healer in the Meratus mountains of South Kalimantan, who linked her hymn to the shamanic codification process. Love songs are easier to reach than many hymns, because they are not covered in secrecy as are hymns and shaman spells and can easily be passed on to others (Tsing, 1998: 359).

Therefore, the important issue to be addressed is that despite the density of religious messages in regional songs, the reality will only be enjoyed by the aesthetics of music and songs, but not in the content of song lyrics. The writer 
will try to fill the empty gap, that the local songs also have religious content, such as Anang Ardiansyah's work which is continuously sung to this day but not much in the study of religiosity and the relation of Banjar culture. This paper will further describe the study of religiosity in the urban Banjar, the framework of thinking about Islam in the local content, biography of Anang Ardiansyah, Banjar songwriters and singers, four selected songs to be discussed in this paper, and Banjar religious practice.

\section{SONGS AND RELIGIOSITY OF URANG BANJAR}

The Islamic practice of urang Banjar (people of Banjar) is often attached as a form of the religion of the Banjar tribe itself who strongly upholds the teachings of Islam (Mujiburrahman, 2017). Urang Banjar are known as an Islamic society. That is seen for example from the rampant religious activities in this community. Architecturally the Banjar area is also known as the area of a thousand langgars (small praying houses). A condition that shows that the Islamic breath is very thick in this area (Noor, 2011: 145-146). This claim is affirmed by various things, among others, through the Banjar community convert from their former religion into adherents of Islam since the first Muslim kingdom of Banjar in the period of Prince Samudera with the title of Sultan Suriansyah as a consequence of the agreement between the sultanate of Demak that provided assistance when raging civil war against Prince Tumenggung, uncle of Prince Samudera (Bondan, 1953). Nevertheless, this history is still criticized, that what is considered to convert to Islam is Prince Samudera and his family as a gratitude, as well as welcoming the future, because at that time Islam was on the rise in the archipelago, in Banua Banjar earlier, but rather slow, conversion had changed quickly because the paternalistic / feudalistic people of Banjar immediately followed their king's religion. But Islam is not preached violently. Although Islam is the official state religion, its spread remained persuasive (Barjie B, 2016: 16).

Furthermore, during the reign of Banjar, a famous scholar named Sheikh Muhammad Arsyad al-Banjari became widely known with his phenomenal work in the form of fiqh book entitled "Kitab Sabilal Muhtadin Lit Tafaquni Fid Din". This book was written at the request of Sultan Tahidullah, written in Malay, in $1193 \mathrm{AH}$, and was completed in $1195 \mathrm{AH}$ (1779-1780) and was first uncovered for the first time simultaneously in $1300 \mathrm{AH}$ (1882 AD) in Mecca, Istanbul and Cairo. This book is well known throughout Southeast Asia such as the Philippines, Malaysia, Singapore, Thailand, Indonesia, Brunei, Cambodia,Vietnam and Laos. Because the Muslims in these areas still use the Malay language as one of the language of instruction in the science of religion (Gratitude, 2003). 
The above opinion is reinforced by Prasojo's study of Islamic teachings using Sabilal Muhtadin's book that goes deep into the hinterland of West Kalimantan, namely Kapuas Hulu to Sarawak, Sabah and Brunei Darussalam (Prasojo, 2017). In addition to the phenomenal book, the practice of Banjar urban religiosity is performed with the various teachings with the mass reaching thousands to tens of thousands as shown by $\mathrm{KH}$ Muhammad Zaini Abdul Gani or popular with the title of Guru Sekumpul, even those who are present at his pengajian (Qur'an recital) or meet him are from the elites such as Head of the District Military Command, Police Chief, Regent, Governor, Head of the Precinct Military Command, to the president and vice president (Rosyadi, 2004). Personally the Guru Sekumpul is considered a charismatic figure who has many advantages or glories and is regarded as waliyullah (Kariem, 2015). The figure of the Guru Sekumpul is of course interesting to be the subject of study, as the emergence of elite groups that play a role in the trade in the area of the city of Martapura, Banjar, shows that the religious and economic behavior of Banjar people has a very close relationship (Alfisyah, 2005). The study further showed that the existence of the Quran recital of Guru Sekumpul also fostered the middle class group in a market-friendly but Islamic-based lifestyle (Hasan, 2016). After the death of Guru Sekumpul in 2005, more teachers or clerics who hold pengajian (Qur'an Recital) with thousands of people such as Guru Juhdi, Guru Bahiet

Another study of Islam is related to the Banjar religious behavior described in various daily activities not only concerning the daily worship in the pillars of Islam i.e. shahada, prayers, fasting, zakat and pilgrimage in Islamic books and Banjar Society. Also discussed is about the pillars of Faith including the belief of spirits, healing ceremonies and various matters related to Banjar religious traditions (Daud, 1997). The book of Islam and Banjar Society has become a kind of master book for anyone who examines the Banjar culture.

Several other writings on the Banjar ethics (Hadi, 2015), Banjar thought or reasoning related to Islam (Noor, 2011), Banjar economic life have been featured in various studies, especially in Islamic economics (Hasan A., 2014). The religiosity of Banjar people is also displayed when the sale and purchase agreement with "selling as it is" is practiced in the purchasing behavior of Banjar people (Nasrullah, 2015). But among various studies, it seems the discussion of religiosity contained in the lyrics of the song has yet to be the subject. Whereas the late KH Muhammad Zaini Abdul, the renowned scholar of South Kalimantan always sang syiar maulid and bamaulidan continues to be part of the Banjar religious culture. Similarly, the songs written by Anang Ardiansyah that contain lyrics of religious verses have not been raised in an 
article despite the fact that they are always played, sung in every opportunity, especially among Banjar people.

\section{RETELLING ISLAM IN LOCAL CONTENT}

The spread of Islam in Indonesia occurred through 'marrying' religious teachings with elements of local culture so that there is mix between traditional beliefs and Islamic teachings, so the practice of religion contains traditions of the past and elements of a novelty (Hermansyah, 2014: 60). In the Dayak community, especially the Bakumpai people in South Kalimantan who are mostly Muslim, they practice Islam and still perform traditional healing such as badewa, and local beliefs that accompany the various anniversaries of the Islamic day (Nasrullah, 2014). This success can also be seen in West Kalimantan, where most sultans are affiliated with the Arab world and some of the royal founders were Arab immigrants who spread Islam on the island of Borneo (Prasojo, 2017).

The 'marriage' between Islamic teachings and local content not only made Islam acceptable but also turned the religion into a movement. The Nyuli movement or the revival of the Dayak Lawangan people in Central Kalimantan has made many adjustments in Islam, even in the outer aspects of Islam are gradually widespread among the Dayaks; therefore in the Nyuli movement there are many true elements of Islamic customs (Mallinckrodt, 1974: 34). In the same era, the resistance of Prince Antasari in Banjarmasin to the Puruk Cahu area of Central Kalimantan to the Dutch is inseparable from the blend of Islamic teachings and local culture. Antasari used the myth of the people associated with his ancestors in the form of the Muning Movement to start a war: he now uses the tariqat in the form of Beratib Beamal to revive the spirit of war (Sjamsuddin, 2001: 256). This movement was allegedly derived from the Naqsyabandiyah or samaniyah tariqa, but it is unclear which is true (Mujiburrahman, 2017: 58) and clearly any of the tarekates of this Beratib beamal, his actions were regarded by the Dutch as a major threat to Dutch authority (Sjamsuddin 2001: 257).

Various opinions above, shows the connection between Dayak tribe and Banjar tribe. Even geographically and administratively, Banjar people are more dominant in South Kalimantan, but actually in many districts there are Dayak communities. This connection can be seen in Barito Kuala district, there are Dayak Bakumpai communities, especially Marabahan and Kuripan districts. In addition, in the western Meratus mountains, there is a fertile lowland rice producer, and swamps called Hulu Sungai, which has since long ago been the fortress of the Banjar people; for many Banjar people in this region, Hulu 
Sungai is a peninsula characterized by civilization of the city surrounded by a vicious sea of "Dayak people" - Meratus in the east; Dusun Lawangan, and sand to the north; Maanyan and Ngaju in the west (Tsing, 1998: 261).

This geographical connection is also rigged with Dayak culture. Bakumpai people as Muslim Dayaks, for example, in Islamic tradition do not change as what has been done regarding Banjar people, so it will be difficult to distinguish between the Bakumpai and Banjar people, except the local language factor used and some traditions as a differentiator between the two Nasrullah, 2014). Even in Islamic spread in the past, Bakumpai area (Marabahan city) through Al Allamah H. Abdussamad, who is the descendant of Sheikh Muhammad Arsyad al-Banjari, that every month of Ramadan came the pious scholars from Martapura, Banjarmasin and Hulu Sungai to visit and studied the science of Tariqat and joined seclusion under his leadership (Anonymous, 2003: 6)

Later in the Banjar and Meratus relationships, the Banjar people in particular need the Meratus in terms of shamanism. Banjar people think the dukun meratus is a witch doctor, so they are expected to treat those who suffer from black magic (Tsing, 1998: 270), whereas for Meratus, the most honorable use of language is not the male language, but the language of outsiders who have authority (i.e., Banjarese language or other Indonesians). That is why there are many terms or words in Banjar and Indonesian which are not used in the daily speech of Meratus (Tsing, 1998: 284).

The relationship between Banjar and Meratus Dayak people in Hulu Sungai area is getting familiar with the existence of an old mosque, named Banua Halat Mosque. This mosque is a manifestation of Banjar and Dayak mythology, especially the Meratus which is considered the siblings of Intingan and Dayuhan which can be seen at baayun maulid ceremony (swinging children on a mosque pole) in every Rabiul Awal month. Therefore, Dayak Meratus Dayuhan descendants who live in Harait, Batung and other villages call the Banua Halat people who are Muslims with the title dangsanak or badangsanak which means brother, because they believe their ancestors were siblings of the ancestors of Banua Halat people (Wajidi, 2014: 214). The strong ties between Banjar and Dayak people, which opened the awareness that the arts of South Kalimantan should not be seen from the religious values of Islam, but the ethnic who live in the mountains, in the interior, and in coastal areas is actually an inseparable part of the sense of "sapadangsanakan" despite their different beliefs (Arijadi, 2013: 180)

The blend of Islam and the local content can be seen as the Living Qu'an is a symbolic universe as well as an interpretable text. As a system of symbols, the Qur'an is not only the object of interpretation of the commentators, but 
it also serves as the interpretation of every Muslim, and even those who are non-Muslims (Ahimsa-Putra, 2012). However, in later developments when Islam is already engraved and rooted in a place, it does not mean that Muslims become static, because Islamic culture in this case evolved into an adaptive culture because religion has been influenced by ideology and market interests (Abdullah, 2010: 119). Such consciousness arises that people speak more often of ideal values, of how things should be in the view of Islam. Very rarely do people speak about the reality of Muslim life itself except for a brief impression and observation, not on the basis of a careful and in-depth study (Mujiburrahman, 2017: 57-58). Therefore, a religion must find an extensive and intensive distributive mode. Not only mosques that can create religious discourse in everyday life, religious museums, historical places, in performances or through music, religious values can be disseminated. The distribution center of values and knowledge of life should be created as much as possible, for example by creating religious dramas or songs, designing buildings with religious styles (Abdullah, 2010: 120).

The problem emerges when the religious teachings in this case Islam in which its adherents have found extensive and intensive distributive methods, such as referring to the religiosity of Banjar people in various aspects, they are sometimes only formalities. In other words, religious rituals are carried out with high intensity and quantity, but at the same time social problems are still emerging, either economically or politically oriented, to the high level of drug abuse as one can see happening in South Kalimantan (Mujiburrahman, 2017). Thus the distribution of values or religious channels such as through regional songs or in particular the Banjar songs of Anang Ardiansyah which are rich with religious messages will be meaningless and just merely chanting a lively regional song. But one of the ways is to tell or revive the religiosity of the songs. The same thing concerns restoring the awareness of the river culture in Urang Banjar by retelling the meaning behind the daily symbols in Banjarmasin Post (Nasrullah, 2017).

\section{BRIEF BIOGRAPHY OF ANANG ARDIANSYAH}

\section{a. Birth}

Anang Ardiansyah was born in Kampung Arab, Banjarmasin. At that time, his parent worked as a kiai. The position of the kiai, or Kiai Kepala (Hoofdkiai), assistant kiai was a special position held by the indigenous civil servants (Wajidi, 2007: 23). Therefore, since childhood Anang Ardiansyah followed his paretns to various regions for duty. His last trip with his father was to East Kalimantan. 
Anang Ardiansyah spent his childhood in Long Iram until he was 5.5 years old. He often followed his father's journey to various rural areas, such as Long Nawang, Long Bagun. Over there, he met with various Dayak community as well as Dayak musical art that is so impressive, like bagantung-gantung, talitali di batis, engrang. Mahakam River and Dayak music later became his source of inspiration in writing songs. For him the art of Dayak music is beautiful, better than the Banjar music because Dayak music art is original with basic melody, although for most people it feels boring.

Childhood was both impressive and sad. In 1942, when he was four years old, the Japanese invaded Kalimantan and captured Tarakan and Balikpapan through the Philippines. At that time, there was a tragedy of the first massacre of the Kalimantan elites by the Japanese army. Japan wanted to make Kalimantan a permanent imperial territory. To pave the way, at the beginning of 1943 Kai-gun committed a massacre of dozens of Kalimantan's elite names, comprising nobles, intellectuals, public figures, and all the rich indigenous people and Chinese. In Mandor, West Kalimantan, Kai-Gun slaughtered 1,534 community leaders. In South Kalimantan (Ulin) and East Kalimantan, the same thing occurred. The exact number of victims of the massacre to date is unknown (Maulani, 2005: 21).

Japanese occupation of only 3.5 years was so cruel and Anang Ardiansyah also felt the deep pain. One afternoon, while playing around at home and being watched by both his parents, suddenly uninvited guests arrived. There were three to four Japanese soldiers coming to his house and forcibly took his father with them. Since then he never saw him again and with his mother he returned to Banjarmasin to be with his extended family.

\section{b. Song Writing Process}

After graduating from Taman Dewasa in 1957 in the city of Banjarmasin, Anang Ardiansyah went to Surabaya to meet his mamarina or relatives from his father's side. Apparently he did not stay long in Surabaya. He moved to Malang, East Java, to study at a high school. While in Malang, he won the fourth place of Lomba Nyanyi Langgam (singing contest). He once became a qari and won 1st place in Malang. Unfortunately, he was only in Malang for a year. He then moved to Surabaya and continued high school.

His musical talent was channeled during high school in Surabaya. At that time there was a group of orchestra called Rindang Banua which means longing for hometown. For Banjar people overseas, listening to Rindang Banua songs make them long for the Banua / birthplace. This group was founded for 7 years 
before Anang entered high school, or circa 1946's. Initially only saw them exercise, but when they were looking for a guitar player, "Who can play the guitar here?" asked the players. Anang was immediately selected. Since then, he joined the orchestra Rindang Banua in Surabaya.

The Rindang Banua group practice at Pak Fahruddin Mohani's hotel, so when they finished practicing they got food from the hotel. In addition to Anang, other players included Adi Maswardi, Saleh Salfas, doctor Bardawi, doctor Arsyadi, etc, with a total of 7 people. All players of Rindang Banua came from Banjar, as well as the owner of Rindang Banua, Fahruddin Mohani, a rich man from Banjar. He also became the owner of the Pelangi Hotel near Jami Mosque in Malang, and opened a hotel branch in Surabaya.

Rindang Banua was founded after a fire in Samarinda. Fahruddin Mohani set up a charitable foundation to help the victims of fire, by calling a famous Latin band Gumarang orchestra from Jakarta to raise funds. After seeing the performance of Gumarang orchestra, Fahruddin then founded a Rindang Banua orchestra with Banjar players. Anang Ardiansyah and other Rindang Banua players learnt from Gumarang players in Jakarta for a week.

According to Anang, Rindang Banua is deeply influenced by the Gumarang group's musical style, whose players come from Minang. The Latin beat combined with the Cha-cha rhythm is known as a dance drummer in Latin America. At the time, Indonesian music was deeply influenced by the western, such as latin and cha-cha. Even Rhoma Irama prior to founding Soneta was infatuated with the Beatles, the Rolling Stones, etc. This phenomenon, created fear among the nationalists, thus the emergence of local music with the term orkes Melayu popularized by DR. A.K. Gani activist of the Islamic States Party (PSI) and Gerakan Rakyat Indonesia (Gerindo) as opposed to Western and Chinese music as well as spreading the spirit of nationalism (Frederick, 1982: 106).

Initially the group Rindang Banua performed without Banjar songs. Then by Pa Yusi, Commander of Military Region (Pangdam) X Lambung Mangkurat whose rank was colonel came to Surabaya and met with players of Rindang Banua. He suggested proposed "coba pang buhan ikam, cari-cari lagu Banjar, mengarang, maulahkah atau apakah" (Try looking for Banjar songs. Write or compose them or what ever you can do). According to Anang, he and his friends accepted the suggestion, after all the Kalimantan people in Java had no songs, while the Aceh people and those of other regions already had their own regional songs. When his friends from Aceh, Java, and other areas asked, "Where is the music of Banjar?" The question made Anang Ardiansyah feel intrigued since then he continued to create and sing Banjar songs. 


\begin{abstract}
ANANG ARDIANSYAH AND HIS FOUR BANJAR SONGS
The songs by Anang Ardiansyah numbered in hundreds. In addition to telling stories about the Banjar culture or society, there are also many stories about the life of the Dayak people in East Kalimantan where he had lived there when he was a child. The song, among others, titled Apo Kayan, Diyang Katinting, and Tingkilan sepanjang Mahakam. But to limit the discussion, the author only discusses four songs by Anang Ardiansyah related to the religiosity of the Banjar, namely: Paris Barantai, Kampung Batuah, Sangu Batulak, and Didundang Disayang. Here is a translation of Banjar songs by Anang Ardiansyah.
\end{abstract}




\section{Translation of Banjar Songs Written by Anang Ardiansyah}

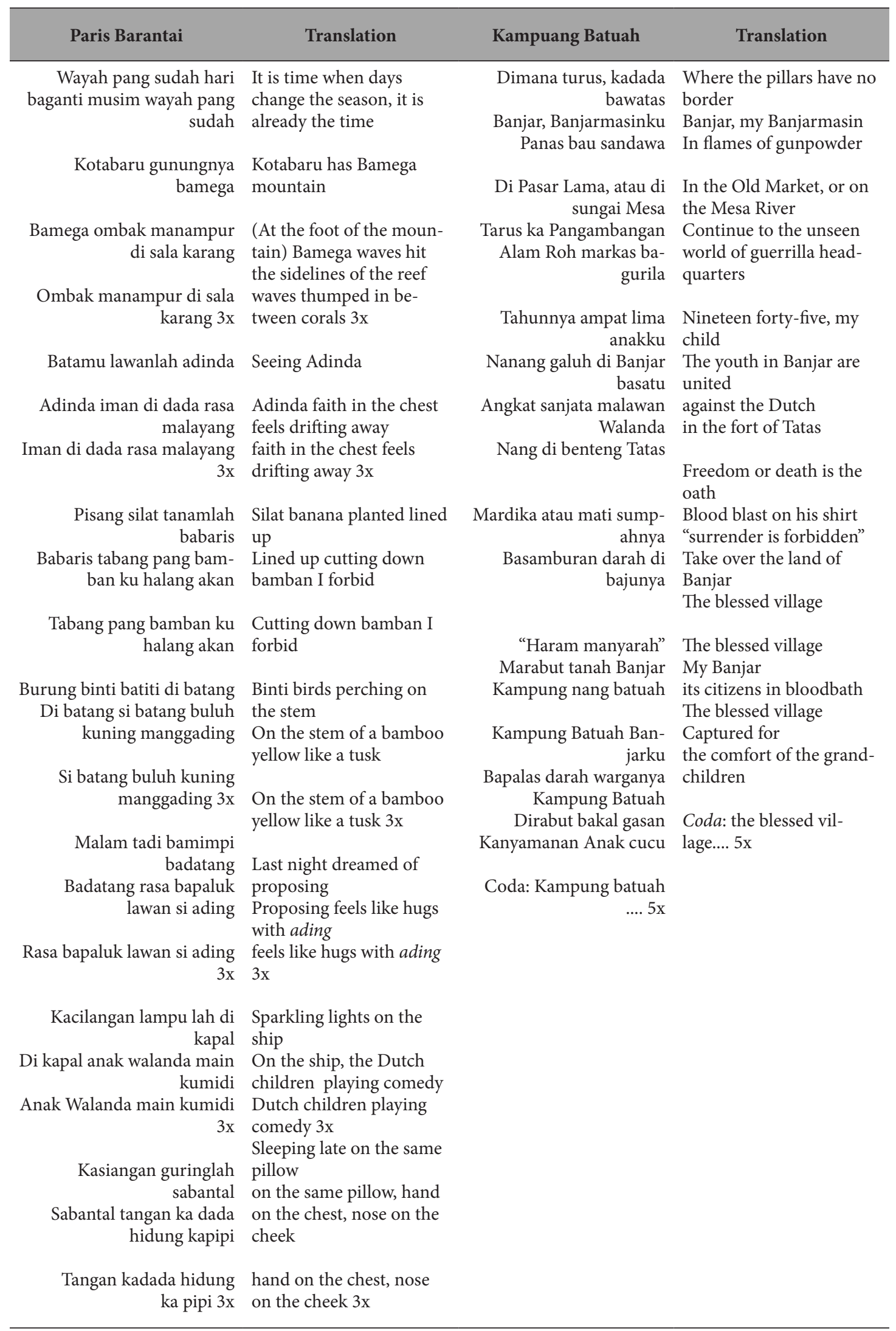




\begin{tabular}{|c|c|c|c|}
\hline Didundang Disayang & Translation & Sangu Batulak & Translation \\
\hline $\begin{array}{r}\text { Arak Pangantin kuliling } \\
\text { kampung }\end{array}$ & $\begin{array}{l}\text { Newly-weds paraded } \\
\text { around the village }\end{array}$ & $\begin{array}{r}\text { Pisang silat pisang } \\
\text { timbatu }\end{array}$ & $\begin{array}{l}\text { Silat banana timbatu } \\
\text { banana }\end{array}$ \\
\hline $\begin{array}{r}\text { Pukul Gandang babunyi } \\
\text { agung }\end{array}$ & $\begin{array}{l}\text { Drums and gongs are } \\
\text { beaten }\end{array}$ & $\begin{array}{r}\text { Kuganganakan bacam- } \\
\text { pur cuka }\end{array}$ & $\begin{array}{l}\text { I cooked them mixed } \\
\text { with vinegar }\end{array}$ \\
\hline $\begin{array}{r}\text { Ading galuh padih di } \\
\text { hati }\end{array}$ & Heartbroken & $\begin{array}{r}\text { Mun jadi tulak, apa } \\
\text { sanguku }\end{array}$ & $\begin{array}{l}\text { If I leave, what to take } \\
\text { with me }\end{array}$ \\
\hline $\begin{array}{r}\text { Larangannya duduk } \\
\text { batatai }\end{array}$ & $\begin{array}{l}\text { Her fiancé sits side by } \\
\text { side }\end{array}$ & $\begin{array}{r}\text { Sahibar doa, iman di } \\
\text { dada }\end{array}$ & $\begin{array}{l}\text { Just prayer, faith in the } \\
\text { chest }\end{array}$ \\
\hline Didundang disayang & $\begin{array}{l}\text { Didundang it's unfortu- } \\
\text { nate }\end{array}$ & $\begin{array}{r}\text { Sambah sujud ampuni } \\
\text { dosa }\end{array}$ & $\begin{array}{l}\text { Worship for forgiveness } \\
\text { of sins }\end{array}$ \\
\hline $\begin{array}{l}\text { Dundang dundang dun- } \\
\text { dang lah disayang }\end{array}$ & $\begin{array}{l}\text { dundang dundang it's } \\
\text { unfortunate }\end{array}$ & Kasih satumat dalam & Love for a moment in the \\
\hline $\begin{array}{r}\text { Ka Palaminan bausung } \\
\text { jinggung }\end{array}$ & $\begin{array}{l}\text { To the wedding throne } \\
\text { carrying the jinggung }\end{array}$ & Kilir-kiliran si banyu & world \\
\hline $\begin{array}{r}\text { Kuda gepang wan ku- } \\
\text { rung-kurung }\end{array}$ & $\begin{array}{l}\text { Kuda gepang and ku- } \\
\text { rung-kurung }\end{array}$ & Kampung nang jauh & $\begin{array}{l}\text { I'm headed for a far away } \\
\text { village }\end{array}$ \\
\hline $\begin{array}{r}\text { Kasiyan galuh duduk di } \\
\text { watun }\end{array}$ & $\begin{array}{l}\text { It's a pity sitting on the } \\
\text { floor }\end{array}$ & $\begin{array}{r}\text { bakal ku tuju } \\
\text { Kampung nang jauh }\end{array}$ & $\begin{array}{l}\text { Reff 2x: Begin with } \\
\text { bismillah }\end{array}$ \\
\hline $\begin{array}{r}\text { Mata basah luruh saru- } \\
\text { dung }\end{array}$ & $\begin{array}{l}\text { Wet eyes are covered } \\
\text { with veils }\end{array}$ & Reff 2x: Mulai lawan & $\begin{array}{l}\text { I take the first step with } \\
\text { my right leg }\end{array}$ \\
\hline Didundang disayang & $\begin{array}{l}\text { Didundang it's unfortu- } \\
\text { nate }\end{array}$ & Batis nang kanan kulang- & $\begin{array}{l}\text { Then submit myself to } \\
\text { Allah }\end{array}$ \\
\hline $\begin{array}{l}\text { Dundang dundang dun- } \\
\text { danglah disayang }\end{array}$ & Dundang dundang dun- & kahakan & That's all I have \\
\hline $\begin{array}{r}\text { Reff: Kada pang sampai } \\
\text { judunya }\end{array}$ & Reff: It's not her soul & $\begin{array}{l}\text { Lalu tawakkal alallah } \\
\text { Itu pang sanguku }\end{array}$ & $\begin{array}{l}\text { Worship for forgiveness } \\
\text { of sins }\end{array}$ \\
\hline $\begin{array}{r}\text { Kasih nang dijunjung, } \\
\text { umai lawasnya }\end{array}$ & $\begin{array}{l}\text { mate } \\
\text { Lover she adores for so }\end{array}$ & $\begin{array}{r}\text { Sambah sujud ampuni } \\
\text { dosa }\end{array}$ & $\begin{array}{l}\text { Love for a moment in the } \\
\text { world }\end{array}$ \\
\hline Sudah pang takdir & & Kasih satumat dalam & Tears roll down \\
\hline $\begin{array}{r}\text { Urang nang ampunya } \\
\text { aaaaa.... }\end{array}$ & $\begin{array}{l}\text { Someone else marries } \\
\text { him aaaa .... }\end{array}$ & $\begin{array}{r}\text { dunia } \\
\text { Kilir-kiliran si banyu }\end{array}$ & $\begin{array}{l}\text { I'm headed for a far away } \\
\text { village Good deeds and }\end{array}$ \\
\hline $\begin{array}{r}\text { Kibar bandira urang } \\
\text { bahaderah }\end{array}$ & $\begin{array}{l}\text { Wave the flag of the } \\
\text { people }\end{array}$ & Kampung nang jauh & faith is all I have \\
\hline $\begin{array}{r}\text { Salawat salam ya nabi- } \\
\text { ullah }\end{array}$ & $\begin{array}{l}\text { Salawat and salam o the } \\
\text { prophet of Allah }\end{array}$ & $\begin{array}{r}\text { bakal ku tuju } \\
\text { Amal wan iman sanguku }\end{array}$ & \\
\hline $\begin{array}{r}\text { Galuh badoa langit } \\
\text { dipandang }\end{array}$ & $\begin{array}{l}\text { Galuh prayed looking up } \\
\text { the sky }\end{array}$ & Coda: Ya Allah, ya Allah & \\
\hline $\begin{array}{r}\text { Mudah-mudahan nang } \\
\text { tuntung pandang }\end{array}$ & $\begin{array}{l}\text { Hopefully a glance (of } \\
\text { happiness) }\end{array}$ & & \\
\hline Didundang disayang & $\begin{array}{l}\text { Didundang it's unfor- } \\
\text { tunate }\end{array}$ & & \\
\hline $\begin{array}{r}\text { Dundang dundang dun- } \\
\text { danglah Disayang }\end{array}$ & $\begin{array}{l}\text { Dundang dundang it's } \\
\text { unfortunate }\end{array}$ & & \\
\hline
\end{tabular}


Paris Barantai is one of the most popular songs by Anang Ardiansyah, but people often refer to this song as "Kotabaru" because the lyric of the song that goes "Kotabaru gunungnya bamega", while the title of the song is not mentioned at all in the whole lyric. The popularity of the song Paris Barantai, among others, is because it is presented in the form of pantun, like the stanza of the song:

\author{
Burung binti batiti di batang \\ Titi batang, di batang buluh \\ Kuning Manggading \\ Malam tadi bamimpilah badatang \\ Rasa datang... rasa bapaluk lawan si ading
}

(Binti birds perching on the stem

On the stem of a bamboo

yellow like a tusk

Last night [I] dreamed of proposing

Proposing feels like hugs with ading)

The lyrics of the song Paris Barantai whose background is Kotabaru, one of the district capital in South Kalimantan, which is located by the sea and tells the longing of a man to the woman who is mentioned as adinda or the ading. In the 1960s the Paris Barantai was recorded in a disc by the Rindang Banua Malay Orchestra and the Ampar-ampar pisang by the Taboneo Malay Orchestra. Both songs are popular and continue to be played Radio Republik Indonesia (RRI) throughout the country. Until now, there is no Banjar song as popular as the two (Syaifullah, 2008).

Still a story about a Banjar woman that is in the song Didundang Disayang. The song Paris Barantai tells about the longing of a man to his lover, on the contrary, the song Didundang Disayang tells about a marriage ceremony that parades the bridegroom around the village. At that time, as the lyrics say a woman called Galuh is grieving because her fiancé as the groom married someone else.

Like the song Paris Barantai, Didundang Disayang, as well as other songs by Anang Ardiansyah titled Kampung Batuah depicts a village in the city of Banjarmasin with a background of the youth's great resistance called Nanang Galuh against the Dutch colonialism. Anang mentioned Banjarmasin as the village of Batuah (the blessed village) which was recaptured (with bloodbath). The struggle is described as an effort or a goal for the future survival of posterity. 
Unlike the other songs, the song Sangu Batulak (things one takes for a journey) tells about the plan of Banjar people to go on a journey. Through this song, Anang Ardiansyah illustrates how hard Banjar people leave their hometown to go far wandering. He describes sadness with tears, and simultaneously drawing sincere intention to wander based on the teachings of Islam.

\section{MULAI LAWAN BISMILLAH AS RELIGIOUS PRACTICE OF URANG $B A N J A R^{1}$}

The majority of Banjar people are Moslems, and it often is claimed that Banjar is synonymous with Islam. They are also famous with their religioity so that the teachings of Islam are practiced in everyday life. The practice of religious teachings is not only observed communally, but also in activities based on personal or respective professions. Similarly, Anang Ardiansyah presents religious values through his songs which tell a lot about Banjar religiosity in various things.

1. Faith is all one has

As the lyric of the song Paris Barantai that goes

Batamu lawanlah adinda.

Adinda iman di dada rasa malayang.

Iman didada rasa malayang.

\section{(Seeing Adinda}

Adinda faith in the chest feels drifting away

faith in the chest feels drifting away)

Repetition of the words "Faith in the chest feels drifting away" twice by the songwriter refers the actions of a person who must consider the values of faith as well as the impact of excessive longing on a lover called "adinda". Faith is always attached under any circumstances, even when experiencing the joy of seeing a loved one. The result of excessive joy or longing makes faith in one's chest assumed to be "drifting away" or faith disappearing from a person. Faith in the chest "should not be abandoned and must be maintained wherever one goes in any activity.

The lyric of Sangu Batulak clarifies the connection of faith in the Banjar religious life.

${ }^{1}$ The word "lawan" in "Mulai Lawan Bismillah" means "with" or "together with" in the Banjar language. 
Part 1

Mun jadi tulak apa sanguku

Sahibar do'a iman di dada

(If I leave, what to take with me

Just prayer, faith in the chest

Part 2

Kampung nang jauh bakal kutuju

Amal wan iman sanguku

(I'm headed for a far away village

Good deeds and faith is all I have)

The verses of the song above show that the song Paris Barantai with its lyric "faith in the chest" which means the faith of a person that dwells in him. The song Sangu Batulak tells the desire of a Banjar person to go wandering, but he has difficulty in leaving his hometown. The journey is called madam (living in a distant place) is not just a tourist trip (traveling) because for the Banjar, the trip serves as worship if equipped with faith. As the verse above confirms the strong position of faith in the lives of Banjar migrants. Part 1 asserts that the plan of departure to be carried out will be based on "prayer of faith in the chest). There is a mix of faith and prayer as what one can take with him in a journey, this may indicate the departure of the Banjar is without skills because there is a word "sahibar" (just) and it also puts the position of faith above all else. The songwriter displays the word "in the chest" to embrace the faith, but if it is associated with the dilemma of the person who is going to wander is actually experiencing the inner conflicts between leaving the home village far away from the family with the desire to wander, then the conflict also occurs in the chest. So that "faith" is to be maintained rather than all the raging inner conflicts in the chest.

In part 2 affirming the capital of the nomads in the overseas lands of "a village I will far go" (going to a distant village) is charity and faith as "sanguku" (modal) ". In the next section as the verse below refers to faith in Allah SWT. 


\author{
Part 3 \\ Mulai lawan "Bismillah" \\ Batis nang kanan kulangkahakan \\ Lalu tawakkal 'alallah \\ Itu pang jadi sanguku \\ (Begin with bismillah \\ I take the first step with my right leg \\ Then submit myself to Allah \\ That's all I have)
}

Part 3 of the song Sangu Batulak clarifies the faith that is addressed to Allah SWT as what one will take on his journey. The songwriter attaches the word "Allah" to the word "Bismillah" to start the right footstep heading to migrate. Also the use of "tawakkal 'alallah" when the nomad is traveling to his destination. The strong religious values of Banjar may have a strong influence on the people in the overseas areas that are visited.

The direct movement of the ancestral land and indirect movement to settle in the transit area contributed to the survival and spread of Islamic propagation and Malay civilization and some evidence of Islamic teachings by Banjar scholars both in Kalimantan and outside as well as in non-Malay lands (Dayak, Dusun) in Kalimantan, especially areas that did not have royalty or sultanate (Arbain, 2013: 24).

\title{
2. Prayer and shalawat
}

For Banjar people all worship and prayer are addressed to God and cannot be addressed to His creatures; nobody grants prayer except Allah (David, 1997: 559). The religiosity of Banjar people is also applied by saying prayer as a solution to the problem of life as in the previous chapter, miserable suffering or heartbreak because her fiancé is married to another woman. The lyric of the song Didundang Disayang are as follows:

Kibar bandira urang bahaderah

Salawat salam ya nabiullah

Galuh badoa langit dipandang

Mudah mudahan nang tuntung pandang 
(Wave the flag of the bahaderah people

Salawat and salam o the prophet of Allah

Galuh prayed looking up the sky

Hopefully there's a glance [of happiness])

In the above verses, the storys is contrasted. On the one hand, the people are enjoying the joy of "waving the flag of the bahaderah people" that is the ceremony of parading the newly-weds with a crowd of people carrying a flag accompanied by the music rhythm and percussion. During the parade, the dancers who performed dancing while waving the flag accompanied by some people singing a compliment to Prophet Muhammad SAW or singing prayers. At the same time, grieving Galuh made a decision by praying while looking up the sky. In such a situation the solution was to pray. At the same time, galuh looks up the sky as the highest and infinite place, she does not look down as she will see the limit of the visibility. Praying is not for herself, but for the good of others, even the good of the former lover who chooses to marry the other woman. Prayer as a solution of this issue can be seen in the song Sangu Batulak, "Mun jadi tulak apa sanguku. Sahibar doa iman di dada" (If I leave, what to take with me? Just prayer, faith in the chest) as described earlier that prayer is a solution to a migrant person with internal conflict because of sadness of leaving hometown.

\section{3. "Haram Manyarah" Banjar people’s struggle doctrine}

Explicitly religious values are not featured in the song Kampung Batuah, but instead it shows the strength of religious doctrine as the foundation against the invaders. The verses of the song "haram korarah marabut Banjar" is a strong doctrine that also does not provide other options to the Banjar people in addition to fighting the invaders. The term "haram menyarah" does not guarantee that they will win the resistance, even the effect is either freedom or death. In addition, the impact of this "haram menyarah" is "his clothes covered in blood". Through the song, the youths of Banjar are given a difficult choice as the impact of their persistent spirit of haram manyarah (surrender is forbidden) to achieve the vision for the future of a village in Banjarmasin i.e. the blessed village which aims for the good of generations to come (children and grandchildren).

If traced further, the term "haram menyarah" is related to, as Andersen put forward, the Banjarmasin war which had political and religious aspects. For some resistance leaders, the war was a war of sabil (Sjamsuddin, 2001: 206). Similarly, the "unseen world" as the guerrilla headquarters shows that 
in the Banjarmasin War this ideology was combined with the messianic and nativistic expectations of the Muning movement. Although the movement itself was short-lived, it became a powerful force in the spirit of jihad. This movement was a kind of assimilation between Islamic teachings and folk traditions (Sjamsuddin, 2001:253)

\section{CONCLUSION}

The existence of art, i.e. the songs of the Banjar region written by Anang Ardiansyah, turned out to be an important part of the identity of religiosity in Banjar culture. This is evident in the following three aspects: First, in the midst of the various world musical streams entering the Borneo region and followed by the present generation, there are still regional songs (using local language and theme) that still survives to be heard and talked about. The power of local content in songs written by Anang Ardiansyah can provide space for Banjar culture with religious nuance to continue to be preserved through songs and appreciation of the song lyrics.

Second, Banjar songs by Anang Ardiansyah are home to civilization or Banjar culture built from the foundation of awareness of the surrounding environment by breathing the spirit of life. The discourse of love or women is part of attraction but fenced by the boundaries of religious values of faith. The basic foundation of all is the awareness of the religiosity of Anang Ardiansyah as a Banjar Muslim whose values of faith, prayer, belief in religious teaching are ingrained in his works. Perhaps that is why his songs are timeless because they are rooted in the the Banjar religious and cultural tradition itself.

Third, Banjar songs are not only aesthetic in meaning or beautiful to the sense of hearing, but the inclusion of religious teachings that are instilled continuously has strengthened the identity of Islam among the Banjar people. At the same time the distribution of religious values and knowledge through regional songs has strengthened by reinterpreting or at least retelling the content of the song's meaning.

\section{THANK-YOU NOTE}

I would like to thank the inheritors of Anang Ardiansyah namely Riswan who has allowed me to use some song scripts and use the data from interviews with the late Anang Ardiansyah in this paper. Hopefully his good deeds will be rewarded by Allah SWT. Amen. 


\section{BIBLIOGRAPHY}

Abdullah, I. (2010). Konstruksi dan Reproduksi Kebudayaan. Yogyakarta: Pustaka Pelajar.

Ahimsa-Putra, H. S. (2012). The Living Al-Quran: Beberapa Persfektif Antropologi. Walisongo, 20(1), 235-260.

Alfisyah. 2005. Agama dan Tingkah Laku Ekonomi Orang Banjar. Universitas Gadjah Mada, Sekolah Pascasarjana. Yogyakarta: Sekolah Pascasarjana.

Alkhalisi, Z. (2017). July 21. CCN Media. Dipetik July 30, 2017, dari @ CNNMoney: http://money.cnn.com/2017/07/20/media/malaysia-ban-despacito-state-media/index.html

Anonim. (2017). Juli 28. banjarmasinpost.co.id. Dipetik 7 29, 2017, dari http://banjarmasin.tribunnews.com/2017/07/28/lagu-paris-barantai-karya-h-anang-ardiansyah-dituliskan-ciptaan-ken-steven

Anonim. 2003. Manaqib 'Alimul 'Allamah al-Qadli H. Abdhusshamad al Mufto H. Jamaluddin bin Maulana Syeikh Muhammad Arsyad al-Banjari. Dinas Pariwisata Seni dan Budaya Kabupaten Barito Kuala

Arbain, T. (2013). Perang Banjar, Migrasi dan Penyebaran Dakwah Islam di Negeri Serumpun Melayu. Dalam Merawat Adat Memaknai Sejarah, Perkembangan dan Peradaban Adat Tradisi Banjar (hal. 15-39). Banjarmasin: UPT Taman Budaya Kalsel Dinas Pemuda Olahraga, Kebudayaan dan Pariwisata Pemerintah Provinsi Kalimantan Selatan dan Pustaka Banua.

Arijadi, A. H. (2013). Kesenian Daerah Kalimantan Selatan sebagai Eksistensi Budaya Banjar. Dalam Merawat Adat Memaknai Sejarah, Perkembangan dan Peradaban Adat Tradisi Banjar (hal. 171-181). Banjarmasin: UPT Taman Budaya Kalsel Dinas Pemuda Olahraga, Kebudayaan dan Pariwisata Pemerintah Provinsi Kalimantan Selatan dan Pustaka Banua.

Barjie B. A. (2016). Kesultanan Banjar Bangkit dan Mengabdi. Banjarmasin: Pustaka Banua.

Bondan, A. H. (1953). Suluh Sedjarah Kalimantan. Banjarmasin: Fadjar.

Daud, A. (1997). Islam dan Masyarakat Banjar: Deskripsi dan Analisa Kebudayaan Banjar. Jakarta: PT RajaGrafindo Persada.

Frederick, W. (1982). Rhoma Irama and The Dangdut Style: Aspect of Contemporary Indonesia Popular Culture. Cornell: Southeast Asia Program Publication Cornell University. 
Hadi, S. (2015). Studi Etika Orang Banjar. Tashwir, 3(6), 209-226.

Hasan, A. (2014). Prospek Pengembangan Ekonomi Syariah di Masyarakat Banjar Kalimantan Selatan. Ahkam, XIV(2), 225-232.

Hasan, N. (2016). Islam di Kota-kota Kelas Menengah Indonesia: Kelas Menengah, Gaya Hidup dan Demokrasi. Dalam G. v. Klinken, \& W. Berenschot (Penyunt.), In Search of Middle Indonesia Kelas Menangah di Kota-kota Menengah (hal. 215-245). Jakarta: KITLV-Jakarta dan Yayasan Pustaka Obor Indonesia.

Hermansyah. (2014). Islam and Local Culture in Indonesia. Al-AlBab, 3(1), $55-66$.

Huizinga, J. (1990). Homo Ludens Fungsi dan Hakekat Permainana dalam Budaya. JakartaL LP3ES.

Ideham, M. S., Djohansjah, Jurliani., Kawi, Djantera., Syarifuddin, Seman, Syamsiar., Usman, G., et al. (2007). Urang Banjar dan Kebudayaannya. (M. S. Ideham, Sjarifuddin, M. A. Anis, \& Wajidi, Penyunt.) Banjarmasin: Badan Penelitian dan Pengembangan Daerah Propinsi Kalimantan Selatan dan Pustaka Banua.

Irama, R. (?). 34 Tahun Tembang Kenangan Rhoma Irama Soneta Group. PT Sani Sentosa Abadi, Jakarta.

Kariem, M. E. (2015). Figur Kharismatik Abah Guru Sekumpul Keteladanan Hidup dari al-Arif Billah Maulana Syekh Muhammad Zaini Banjar. Binuang: Pondok Pesantren Darul Muhibbien bekerjasama dengan Bina Aswaja.

Mallinckrodt, J. (1974). Gerakan Nyuli di Kalangan Suku Dayak Lawangan. Jakarta: Bhratara.

Maulani, Z. A. (2005). Melaksanakan Kewajiban Kepada Tuhan dan Tanah Air Memoar Seorang Prajurit TINI. Jakarta: Daseta.

Melalatoa, M. J. (2000). Kesenian Indonesia. Antropologi Indonesia, XXIV(62), 1-7.

Muchamad, B. N., \& Mentayani, I. (2007). Anatomi Rumah Bubungan Tinggi. Banjarmasin: Pustaka Banua.

Mujiburrahman. (2017). Urgensi Memahami Banua Melalui Kajian Sosiologi Agama. Khazanah, XV(1), 53-69.

Mundayat, A. A. (2006). Djoko Pekik Seni Sebagai Ekspresi Kritik. Dalam A. M. Wattie, A. A. Mundayat, A. Triratnawati, H. Poerwanto, H. S. Ahimsa-Putra, P. Laksono, et al., Esei-esei Antropologi: Teori, Metodologi dan Ethnografi (hal. 240 - 257). Yogyakarta: Kepel Press. 
Nasrullah. (2014). The Islamic Tradition of Bakumpai Dayak People. Al-AlBab, 3(1), 39-54.

(2015). Jual Seadanya (Telah Antropologis terhadap Implementasi Ajaran Islam dalam. Banjarmasin: Konferensi Internasional Transformasi Sosial Dan Intelektual Orang Banjar Kontemporer diselenggarakan IAIN Antasari.

(2017). Mengenang Kembali Peradaban Sungai (Kajian terhadap Simbol Banjarmasin Post). Dalam M. A. Soendjoto, A. Prahatamaputra, \& M. K. Riefani (Penyunt.), Prosiding Seminar Nasional Lahan Basah tahun 2016 Jilid 2 Potensi, Peluang dan Tantangan Pengelolaan Lingkungan Hidup Lahan Basah secara Berkelanjutan (hal. 467-473). Banjarmasin: Lambung Mangkurat University Press.

Noor, M. I. (2011). Nalar Keislaman Urang Banjar. Al-Banjari, 10(2), 145-164.

Prasojo, Z. H. (2017). Religious and Cultural Existence Within the Communities of Upper Kapuas Riverside of West Kalimantan. Al-AlBab, 6(2), 197-214.

Rasusmen, A. K. (2005). The Arab Musical Aesthetic in Indonesia. The World of Music, 47(1), 65-89.

Rosyadi, A. (2004). Bertamu ke Sekumpul Mereka yang Bertemu dengan KH Muhammad Zaini Abdul Gani. Yogyakarta: Lembaga Pengkajian Ilmu Pengetahuan dan Keislaman Kabupaten Banjar.

Sjamsuddin, H. (2001). Pegustian dan Temenggung, Akar Sosial, Politik, Etnis, dan Dinasti. Perlawanan di Kalimantan Selatan dan Tengah 18591906. Jakarta: Balai Pustaka.

Syaifullah, M. (2008). Desember 3. Oase. Dipetik Juli 29, 2017, dari Kompas. com: http://nasional.kompas.com/read/2008/12/03/20384815/anang. ardiansyah.maestro.lagu.banjar

Syukur, A. (2003). Kata Pengantar Penyalin. Dalam S. M. al-Banjari, Kitab Sabilal Muhtadin 1 (H. A. Syukur, Penerj., hal. xi-xiii). Surabaya: PT Bina Ilmu.

Tsing, A. L. (1998). Di Bawah Bayang-bayang Ratu Intan Proses Marginalisasi Pada Masyarakat Terasing. Jakarta: Yayasan Obor Indonesia

Wajidi. (2007). Nasionalisme Indonesia di Kalimantan Selatan 1901-1942. Banjarmasin: Pustaka Banua.

(2014). Dialektika Islam dan Budaya dalam Tradisi Ba-Ayun Maulid di Masjid Banua Halat Kabupaten Tapin. Jurnal Kebijakan Pembangunan, 9(2). 211-224. 